\title{
MENGOPTIMALKAN KEMAMPUAN FISIK MOTORIK ANAK USIA 3-4 TAHUN MELALUI KEGIATAN BERMAIN LEMPAR TANGKAP BOLA
}

\author{
Sumiyati \\ Institut Pesantren Mathali'ul Falah Pati \\ Jl. Pati-Tayu Km. 20 Margoyoso Jawa Tengah \\ E-mail: atikpaudi@mail.com
}

\begin{abstract}
The development of motor functions is one of the dimensions of early childhood development that is important to note among other development dimensions. This is a fundamental part of the child's need to develop muscle, brain, and nerves, which is one of the basic developments at a later stage. Therefore, this dimension needs to get appropriate stimulation in accordance with the stages of child development, so that stimulation is given with the right portion. One of the most effective ways to develop children motor skills is through their favorite activities, such as fun and play activities. This paper tries to explain one of the fun activity alternatives that could be used to optimize the motor physical ability of children aged 3-4 years, ie through, among others, throwing ball games. It is hoped that this paper is useful for early childhood education practitioners, as well as parents in developing ways to stimulate the development of motor skills of early childhood through fun activities.
\end{abstract}

Keywords: Motor Physical Ability, Trowing Ball Game

\section{Pendahuluan}

Masa kanak-kanak merupakan masa yang paling penting dalam kehidupan seorang anak. Usia dini sering disebut masa keemasan, karena berharganya masa ini. Rentang usia emas ini berada pada usia 0-6 tahun. Di masa inilah anak akan memiliki pertumbuhan dan perkembangan yang tidak akan bisa terulang lagi di usia-usia anak selanjutnya. ${ }^{1}$ Semakin meningkatnya pemahaman dan kesadaran orangtua tentang arti pentingnya Pendidikan Anak Usia Dini (PAUD), dan maraknya lembaga-lembaga PAUD sekarang ini, maka memberi banyak pilihan kepada orangtua untuk memberikan fasilitas pendidikan sedini mungkin kepada anak-anak, sebagai pondasi anak menyongsong taha pendidikan selanjutnya.

Lembaga PAUD seperti Taman Kanak-kanak (TK), Raudhatul Athfal (RA), Kelompok Bermain (KB), Taman Penitipan Anak (TPA) dan Satuan PAUD Sejenis (SPS) lainnya telah banyak menawarkan program-program guna mengoptimalkan pertumbuhan dan perkembangan anak usia dini. Akan tetapi perbedaan pandangan dan pemahaman tentang arti pentingnya pendidikan anak usia dini yang tidak sama, terkadang membuat ketidaktepatan dalam memaknai pendidikan anak usia dini ini. Seperti adanya harapan-harapan orangtua terhadap tujuan pendidikan anak usia dini. Ada orangtua yang lebih bersifat praktis dalam melihat perkembangan anak dari sisi intelektual saja, ada pula orangtua yang berharap anaknya langsung bisa membaca dan menulis sesudah masuk PAUD dan sebagainya. Bahkan ada orangtua yang justru tidak suka jika anaknya diajak bermain dan bernyanyi di PAUD. ${ }^{2}$

\footnotetext{
${ }^{1}$ Samsunuwiyati Mar'at, Psikologi Perkembangan (Bandung: PT Remaja Rosdakarya, 2005)

${ }^{2}$ Maimunah Hasan, Pendidikan Anak Usia Dini (Jogjakarta: Diva Perss, 2012)
} 
Harapan-haraapan orangtua tersebut terkadang tidak selaras dengan apa yang menjadi tujuan pembelajaran di PAUD. Padahal banyak aspek yang perlu dikembangkan pada anak usia dini, di mana perkembangan tersebut saling terkait dan berhubungan. Salah satu perkembangan tersebut adalah perkembanganan fisik motorik. Perkembangan fisik motorik merupakan bagian perkembangan anak yang tidak kalah penting dibanding dengan perkembangan-perkembangan anak yang lain.

Salah satu cara mengembangkan kemampuan fisik motorik anak yang paling efektif adalah melalui kegiatan yang paling disukai anak-anak, yaitu melalui kegiatan bermain. Semua aspek perkembangan anak sebaiknya dilakukan dengan cara-cara yang menyenangkan. Cara-cara yang menyenangkan tersebut adalah melalui kegiatan bermain. ${ }^{3}$ Hal ini sesuai dengan prinsip pembelajaran anak usia dini yaitu belajar melalui kegiatan bermain. Bermain adalah cara terbaik dan paling efektif untuk menstimulasi kemampuan fisik motorik anak. Sehingga orangtua dan pendidik perlu menyadari pentingnya kegiatan bermain untuk mengoptimalkan perkembangan fisik motorik anak. Dengan demikian diharapkan orangtua dan pendidik dapat memfasilitasi kebutuhan bermain anak.

Di usia emas anak akan selalu beraktifitas seolah tidak bisa dihentikan. Sehingga terkadang orangtua dan pendidik memiliki anggapan bahwa anak ini "hiperaktif" bahkan kadang muncul label "anak nakal". Anak usia 3-4 tahun memiliki keingintahuan yang luar biasa terhadap sesuatu hal. Di rumah bisa saja anak akan mengacak-acak isi lemari, karena belum mampu mengambil benda dengan terampil. Menumpahkan minuman dan makanan di mana-mana karena belum mampu memegang cangkir dengan benar. Atau bahkan sering terjatuh dengan lutut yang lecet karena belum memiliki keseimbangan ketika berjalan. Hal ini menunjukkan bahwa anak sedang berproses untuk bisa, dan seharusnya orangtua dan pendidik dapat memberikan lebih banyak kesempatan pada anak. Salah satu cara yang bisa dilakukan dan dikembangkan oleh orangtua dan guru untuk mengembangkan kemampuan fisik motorik anak adalah dengan bermain lembar tangkap bola.

\section{Urgensi Perkembangan Fisik Motorik Anak}

Perkembangan fisik motorik merupakan salah satu perkembangan mendasar yang dibutuhkan anak untuk proses tumbuh kembang selanjutnya. Perkembangan motorik adalah kegiatan yang berhubungan dengan otot, otak, dan syaraf. ${ }^{4}$ Ketiga hal ini saling memiliki keterkaitan, dan saling terkoordinasi antara satu dengan yang lain. Otot, otak, dan syaraf untuk dapat berkembang dengan maksimal perlu mendapatkan stimulasi yang tepat sesuai dengan tahapan perkembangan anak, sehingga stimulasi diberikan dengan porsi yang tepat.

Pada usia dini perkembangan anak terjadi sangat cepat. Termasuk perkembangan fisik motorik terjadi dengan begitu pesat. Perkembangan motorik tidak saja mencakup berjalan, berlari, melompat, naik sepeda roda tiga, mendorong, menarik, memutar dan berbagai aktivitas koordinasi mata tangan, namun juga melibatkan hal-hal seperti menggambar, mengecat, mencoret dan kegiatan lain. Keterampilan motorik berkembang pesat pada usia

\footnotetext{
${ }^{3}$ Soemiarti Patmonodewo, Pendidikan Anak Prasekolah (Jakarta: Rineka Cipta, 2003)

${ }^{4}$ Dwi Hardiyanti dan M. Sukiram, Strategi Pengembangan Moral Anak Usia Dini (Salatiga: Widyasari Press, 2008), 54.
} 
ini. ${ }^{5}$ Dengan banyaknya hal yang berkaitan dengan perkembangan fisik motorik anak, maka perlu kegiatan yang dapat mewadahi aktifitas-aktifitas terkait pengembagnan fisik motorik anak usia dini ini.

Perkembangan fisik motorik pada anak usia dini dapat dilihat dan dibedakan menjadi dua macam, yaitu motorik kasar dan motorik halus. Motorik kasar berkaitan dengan kemampuan anak dalam berbagai fungsi motorik yang mudah untuk dilihat, motorik kasar ini lebih menekankan pada gerakan otot, seperti: berlari, meliuk-liukkan badan, menendang bola, maupun menggerak-gerakkan kepala. Sedangkan motorik halus lebih menekankan pada kegiatan yang berhubungan dengan otak dan syaraf, seperti: menggambar dan melukis. ${ }^{6}$ Kemampuan motorik kasar anak lebih mudah terlihat karena cenderung menimbulkan gerakan dan memerlukan energi yang cukup besar. Sedangkan motorik halus lebih kepada keseimbangan dan fokus penggunaan otot-otot tertentu, seperti otot-otot jari, dengan kegiatan seperti menulis, meronce, merobek dan kegiatan-kegiatan yang memerlukan ketelitian dan kesabaran. Sehingga keseimbangan dan fokus kegiatan menjadi penting untuk mengembangkan motorik halus anak.

Dengan demikian, kegiatan pengembangan fisik motorik anak dapat dilakukan secara bersamaan antara pengembangan motorik kasar anak dan pengembangan motorik halus anak, meskipun kegiatan stimulasi juga dapat dilakukan secara terpisah untuk lebih mengembangkan kemampuan fisik motorik tertentu baik motorik halus maupun motorik kasar.

\section{Tingkat Pencapaian Perkembangan fisik motorik anak usia 3-4 tahun}

Tingkat Pencapaian Perkembangan (TPP) anak usia 3-4 tahun dapat dilihat dari tabel di bawah ini, sebagaimana yang tercantum dalam kurikulum PAUD 2013:

\section{Tabel 1.Tingkat Pencapaian Perkembangan Fisik Motorik}

Anak Usia 3-4 Tahun ${ }^{7}$

\begin{tabular}{|l|l|}
\hline \multicolumn{1}{|c|}{ Aspek } & \multicolumn{1}{|c|}{ Karakteristik Perilaku (Usia 3-4 tahun) } \\
\hline 1. Motorik Kasar & $\begin{array}{l}\text { a) Berlari sambil membawa sesuatu yang ringan (bola) } \\
\text { b)Naik-turun tangga atau tempat yang lebih tinggi dengan kaki } \\
\text { bergantian } \\
\text { c) Meniti di atas papan yang cukup lebar } \\
\text { d)Melompat turun dari ketinggian kurang lebih } 20 \mathrm{~cm} \text { (di bawah } \\
\text { tinggi lutut anak) } \\
\text { e)Meniru gerakan senam sederhana seperti menirukan gerakan } \\
\text { pohon, kelinci melompat) } \\
\text { f) Berdiri dengan satu kaki }\end{array}$ \\
\hline 2. Motorik Halus & a)Menuang air, pasir, atau biji-bijian ke dalam tempat penampung \\
\hline
\end{tabular}

\footnotetext{
5 Akbar, Reni dan Hawadi, Psikologi Perkembangan Anak: Mengenal Sifat, Bakat, dan Kemampuan Anak (Jakarta: Grasindo, 2001), 7.

${ }^{6}$ Jamun, dkk., Pedoman Penyusunan Perangkat Pembelajaran RA/BA (Semarang: Kementerian Agama Kanwil Provinsi Jawa Tengah, 2011), 131.

${ }^{7}$ Permendikbud 2014 Nomor 137 tentang Standar Nasional Pendidikan Anak Usia Dini (PAUD) Lampiran I
} 


\begin{tabular}{|l|l|}
\hline & \multicolumn{1}{|c|}{$\begin{array}{l}\text { (mangkuk, ember) } \\
\text { b) Memasukkan benda kecil ke dalam botol (potongan lidi, kerikil, } \\
\text { biji-bijian) } \\
\text { c) Meronce benda yang cukup besar } \\
\text { d)Menggunting kertas mengikuti pola garis lurus }\end{array}$} \\
\hline $\begin{array}{l}\text { 3. Kesehatan dan } \\
\text { Perilaku }\end{array}$ & $\begin{array}{l}\text { a) Berat badan sesuai Tingkat usia } \\
\text { b) Tinggi badan sesuai Tingkat usia } \\
\text { c) Berat badan sesuai dengan standar tinggi badan } \\
\text { d) Lingkar kepala sesuai Tingkat usia Membersihkan kotoran } \\
\text { (ingus) } \\
\text { e) Menggosok gigi } \\
\text { f) Memahami arti warna lampu lalu lintas Mengelap tangan dan } \\
\text { muka sendiri } \\
\text { g) Memahami kalau berjalan di sebelah kiri }\end{array}$ \\
\hline
\end{tabular}

Perkembangan fisik motorik di atas memperlihatkan tingkat pencapaian perkembangan yang dapat dicapai oleh anak usia 3-4 tahun. Di mana dengan mengetahui tingkat perkembangan fisik motorik tersebut dapat membuat pendidik dan orangtua untuk merancang kegiatan main yang menarik bagi anak untuk memaksimalkan perkembangan fisik motoriknya.

\section{Bermain Lempar Tangkap Bola}

Bermain merupakan kegiatan yang sangat menyenangkan untuk anak. Dengan kegiatan bermain, anak akan belajar segala sesuatu dengan sangat nyaman dan menyenangkan tanpa adanya unsur pemaksaan. Bermain adalah hak yang harus dimiliki oleh setiap anak yang memiliki peran penting dalam perkembangan anak. Kegiatan bermain bagi anak usia dini sangat berpengaruh dalam perkembangan-perkembangan selanjutnya. Bermain bagi seorang anak tidak sekedar rutinitas, tetapi media untuk belajar. Setiap bentuk kegiatan bermain pada anak usia dini mempunyai nilai positif terhadap tumbuh kembang anak. ${ }^{8}$

Pada kegiatan bermain, anak memiliki kesempatan untuk bereksplorasi dan mengekspresikan segala sesuatu yang dirasa dan diinginkannya. Melalui kegiatan bermain tersebut, anak sebenarnya sedang menggali pengetahuan dan keterampilan serta tidak akan merasa puas jika apa yang diinginkannya belum tercapai, sehingga kadang anak sampai lupa waktu jika sedang asyik bermain. Di dalam kegiatan bermain ini pula, anak dapat mengembangkan motorik kasar dan halus, meningkatkan penalaran, dan memahami keberadaan lingkungannya, membentuk daya imajinasi, daya fantasi, dan kreativitas.

Bermain lempar tangkap bola merupakan salah satu permainan yang dapat dilakukan dengan mudah oleh anak usia 3-4 tahun. Permainan ini dapat mengembangkan fisik motorik anak dengan baik. Baik pengembangan fisik motorik kasar anak, maupun fisik motorik halus anak. Bola juga merupakan alat permainan yang mudah ditemukan. Sehingga anak-anak mudah mengenalinya, serta dapat memainkannya dengan instruksi yang mudah, bahkan hanya

\footnotetext{
${ }^{8}$ Mayke S. Tedjasaputra. Bermain, Mainan, dan Permainan (Jakarta:Gramedia, 2007)
} 
dengan melihat atau meniru bagaimana orang dewasa dapat memainkan bola tersebut, seperti bagaimana cara menangkap dan melemparnya.

Permainan lempar tangkap bola termasuk jenis permainan yang membutuhkan interaksi sosial. Karenan permainan ini membutuhkan kehadiran orang lain, sehingga selain mengembangkan fisik motorik anak, sebenarnya juga dapat mengembangkan kemampuankemampuan anak yang lain, seperti kemampuan sosial emosioanal dan lain sebagainya. Dengan bermain lempar tangkap bola yang membutuhkan peran orang lain, maka anak juga akan belajar mengurangi sikap egosentrisnya, yaitu sikap ke'aku'annya.

Kegiatan yang dapat dilakukan untuk membangun rasa sosial anak dapat dilaksanakan dengan cara bermain sosial (social play). Dengan kegiatan bermain sosial, anak dapat berinterkasi secara langsung dengan orang lain disekitarnya, anak dapat belajar bekerja sama dan menyesuaikan diri dengan lingkungannya. Dengan demikian lambat laun sifat egosentrisme anak akan berkurang. ${ }^{9}$ Anakpun akan mudah menerima kehadiran orang lain, dan sifat sosial anak dapat mulai bertumbuh. Kegiatan bermain lempar tangkap bola dapat dilakukan di mana saja, baik di lingkungan sekolah maupun di lingkungan rumah sekalipun. Sehingga baik pendidik maupun orangtua dapat melakukanny dengan mudah.

Hal yang perlu diperhatikan dalam bermain lempar tangkap bola adalah media yang digunakannya. Media utama yang digunakan tentu saja adalah bola. Ukuran bola untuk anak usia 3-4 tahun tidak perlu memakai bola yang besar, apalagi bola yang digunakan untuk bermain sepak bola oleh orang dewasa pada umumnya, tentunya hal ini akan menyulitkan anak. Bola yang digunakan sebaiknya menyesuaikan dengan kemampuan anak dalam memegang bola, jangan sampai kebesaran atau bahkan kekecilan ketika dipengang. Bermain lempar tangkap bola bisa dimulai dengan bola warna-warni yang mudah ditemukan di pasaran, atau yanng sering kita lihat saat anak-anak bermain mandi bola, selain sesuai untuk ukuran tangan anak, dengan warnanya yang menarik, atau berwarna-warni dapat menumbuhkan semangat anak untuk bermain.

Pada anak usia 3-4 tahun permainan lempar tangkap bola dapat dilakukan dari jarak yang dekat terlebih dahulu. Misal dari jarak 3-4 langkah. Diperhatikan jaraknya supaya anak tidak kesulitan. Seiring dengan bertambahnya usia anak, dan seringnya kegiatan ini dilakukan, maka anakpun akan semakin mahir sehingga jarak dapat ditambah secara bertahap. Demikian saat berlatih untuk melempar, maka kadang kita dapati banyak anak-anak yang sekedar asal melempar dan lebih cocok kalau sekedar 'membuang' bolanya. Hal ini tidak menjadi masalah karena anak akan belajar bagaimana menjaga keseimbangan arah bola dan koordinasi otototot jarinya agar dapat memegang bola dengan tepat, serta melemparkan ke arah teman main dengan baik, di sinilah kemampuan motorik halus anak akan terstimulasi. Sesekali anak juga akan berlari dan bahkan menutup mukanya karena takut terkena lemparan bola, atau justru menampel bolanya sehingga bukannya ditangkap tapi di pukul agar bolanya tidak terkena dirinya, nah ini juga bagian dari bagaimana anak berlatih mengkoordinasikan antara otot, otak dan syarafnya.

Dalam bermain lempar tangkap bola ini tidak jarang kita jumpai anak akan berlari ke sana dan kemari mengejar bola, sesekali mungkin terjatuh. Anak usia 3-4 tahun ini akan berusaha berlari atau berjalan menuju ke arah bola yang sedang dimainkan. Dengan demikian

\footnotetext{
${ }^{9}$ Ibid., 32.
} 
motorik kasar anak juga dapat terstimulasi dengan baik. Anak usia ini cenderung berlari tanpa keseimbangan, sehingga mudah terjatuh. Jika kegiatan ini terjadi terus menerus, maka motorik kasar anak akan berkembang dengan baik. Anakpun akan mulai berjalan dan berlari dengan memperhatikan arah.

\section{Penutup}

Pertumbuhan dan perkembangan anak usia dini merupakan hal yang tidak dapat dipisahkan dalam setiap tahap kehidupan manusia. Anak usia dini yaitu usia 0-6 tahun merupakan usia yang sangat luar biasa dalam hal tumbuh kembang. Sehingga usia ini sering disebut golden ages atau usia emas, mengingat pentingnya masa-masa ini.

Salah satu aspek perkembangan yang penting di usia ini adalah perkembangan fisik motorik. Meskipun pertumbuhan dan perkembangan anak adalah sesuatu yang dapat diramalkan, akan tetapi untuk dapat tumbuh dan berkembang dengan baik, anak membutuhkan dukungan dan stimulasi yang baik dari orangtua dan lingkungan sekitar. Anak membutuhkan model dan stimulasi agar dapat berkembang sesuai harapan dan sesuai dengan tugas perkembangan di usianya.

Bermain lempar tangkap bola adalah bagian dari permainan yang dapat mengembangkan kemampuan fisik motorik anak. Bermain lempar tangkap bola juga merupakan kegiatan yang menyenangkan dan hampir disukai oleh semua anak, termasuk anak yang baru berusia 3-4 tahun. Tentu saja media yang digunakan harus sesuai dengan tahap perkembangan anak di usia ini. Kegiatan lempar tangkap bola selain mengembangkan fisik motorik anak, juga dapat mengembangkan aspek yang lain seperti aspek sosial emosional anak.

Orangtua maupun pendidik dapat melakukan kegiatan bermain lempar tangkap bola ini dengan mudah. Sehingga stimulasi fisik motorik anak tidak hanya di lakukan di lembaga Pendidikan Anak Usia Dini (PAUD) saja, tetapi juga dapat dilakukan di rumah.

\section{Daftar Rujukan}

Akbar, Reni. dan Hawadi. Psikologi Perkembangan Anak: Mengenal Sifat, Bakat, dan Kemampuan Anak, Jakarta: Grasindo, 2001.

al-'Abrasyi, M. Atiyyah. Beberapa Pemikiran Pendidikan Islam, Penerj. Syamsuddin Asyrofi, dkk., Yogyakarta: Titian Ilahi Press, 1996.

Berk, Laura E. Development Throuhg The Lifespan $4^{\text {th }}$ ed, USA: 2006

Hardiyanti, Dwi dan M. Sukiram, Strategi Pengembangan Moral Anak Usia Dini, Salatiga: Widyasari Press, 2008.

Hasan, Maimunah. Pendidikan Anak Usia Dini, Jogjakarta: Diva Perss, 2012.

Jamun, dkk. Pedoman Penyusunan Perangkat Pembelajaran RA/BA, Semarang: Kementerian Agama Kanwil Provinsi Jawa Tengah, 2011.

Mar'at, Samsunuwiyati. Psikologi Perkembangan, Bandung: PT Remaja Rosdakarya, 2005.

Patmonodewo, Soemiarti. Pendidikan Anak Prasekolah, Jakarta: Rineka Cipta, 2003.

Permendikbud 2014 Nomor 137 tentang Standar Nasional Pendidikan Anak Usia Dini (PAUD), Lampiran I

Santrock, J. W. Perkembangan Anak "terj." Mila Rachmawati, Anna Kuswanti, Jakarta: Penerbit Erlangga, 2007. 
Suhartono, Suparlan. Filsafat Pendidikan, Jogjakarta: Ar-Ruzz Media, 2008.

Suyanto, Selamet. Dasar-Dasar Pendidikan Anak Usia Dini, Yogyakarta: Hikayat Publishing, 2005.

Tedjasaputra, Mayke S. Bermain, Mainan, dan Permainan, Jakarta: Gramedia, 2007. 